\title{
Mip protein of Legionella pneumophila exhibits peptidyl-prolyl-cis/trans isomerase (PPlase) activity
}

\author{
Gunter Flscher, ${ }^{1}$ Holger Bang, ${ }^{1}$ Birgit Ludwig, ${ }^{2}$ \\ Karlheinz Mann ${ }^{3}$ and Jörg Hacker ${ }^{2 *}$ \\ 'Max-Planck-Gesellschaft, Arbeitsgruppe 'Enzymologie \\ der Peptidbindung', Halle, Weinbergweg 16a, D-0-4050 \\ Halle/Salle, Germany. \\ ${ }^{2}$ Theodor Boveri Instilut für Biowissenschaften der \\ Universităt Würzburg, Röntgenring 11, D-W-8700 \\ Würzburg, Germany. \\ ${ }^{3}$ Max-Planck-Instlut für Biochemio, Am Klopferspitz, D. \\ W-8033 Martinsried, Germany.
}

\section{Summary}

Legionella pneumophlla is an intracellular parasite which ls able to survive and multiply in human monocytes and alveolar macrophages. The Mip (macrophage infectivity potentiator) proteln has been shown to be an essentlal virulence factor. A search of translated nuclelc acld data bases has shown that the Mip protein from strain Wadsworth possesses reglons homologous to those found In the FK506-binding proteins (FKBPs) of several different eukaryotlc organIsms. FKBPs are able to bind to the Immunosuppressant macrollde FK506 and possess peptidyl-prolyl cisltrans isomerase (PPlase) activity. The gene codIng for the Mlp proteln was cloned from the chromosome of L. pnoumophilla strain Phlladelphla I and sequenced. It was synthesized in Escherichla coll K12 and after purification it exhibited PPlase actlvity catalysing the slow cisitrans isomerization of prolyl peptide bonds in ollgopeptides. Mip is inhibited by FK506 and fully resistant to cyclosporin A, as was also found for the recently characterized FKBP-type PPlases of eukaryotes. However, the N-terminal extension of Mip and/or the substitutions of the varlable amino acids in the Cterminal FKBP core lead to varlations, when compared with oukaryotic FKBPs, in substrate speclificity with the ollgopeptide substrates of type Suc-Ala-Xaa-Pro-Pho-4-nitroanillde. Novertheless, the Leglonella Mip factor represents a bacterial gene product which shares some characteristics normally found In eukaryotic protelns. In view of the

Received 22 November, 1991; revised and accepted 10 February, 1992. "For correspondence. Tel. (931) 31378/31575; Fax (931) 571954. actlvity of PPlases in protein-folding reactions, such prokaryotic FKBP analogues may represent a new class of bacterial pathogenicity factors.

\section{Introduction}

Legionella pneumophila is the aetiological agent of Legionnaires' disease, a distinct form of pneumoniae in humans (McDade ot al., 1977; Winn, 1988; Honwitz, 1988). The bacterium multiplies intracellularly in human blood monocytes, human alveolar macrophages and tissue-culture cells. L pneumophila is phagocytosed by an unusual coiling phagocytosis mechanism (Horwitz, 1984) and is able to inhibit phagosome-lysosome fusion and phagosome acidification of the phagocytes (Horwitz, 1983; Horwitz and Maxfield, 1984; Horwitz, 1988).

In order to identily the gene products involved in the pathogenesis of L. pneumophila (for a review, see Engleberg and Eisenstein, 1991) the determinants coding for two toxins and for three different protein antigens have been cloned and sequenced (Black et al., 1990; Wintermeyer et al., 1992; in preparation; Hoffman et al., 1990; Engleberg et al., 1989; Ludwig et al., 1991). To date, only the Mip (macrophage infectivity potentiator) protein, a polypeptide of $24 \mathrm{kDa}$, is known to contribute to the virulence of $L$ pneumophila (Cianciotto et al., 1989; 1990b). Using isogenic Legionella strains with and without an intact mip gene it was shown that Mip potentiates the uptake of $L$. pneumophila by macrophages and/or contributes to early survival processes in the phagocytic cell. The amino acid sequence of the C-terminal part of the Mip protein was deduced from the DNA sequence of the mip gene from strain Wadsworth (Engleberg et al., 1989) and revealed homology to the sequences of FK506-binding proteins (FKBPs) found in various eukaryotic organisms (Standaert et al., 1990; Maki et al., 1990; Tropschug et al., 1990; Wiederrecht ot al., 1991; Jin ot al., 1991; Lane et al., 1991). The eukaryotic FKBPs are able to bind to the immunosuppressant macrolide, FK506. FKBPs and cyclophilins form the substance class of the immunophilins (Schrelber, 1991). The latter have the capacity to bind cyclosporin A (Fischer et al., 1989; Price ot al., 1991). Immunophilins possess peptidyl-prolyl cistrans isomerase (PPlase) activity and catalyse the slow isomerization of prolyl bonds in oligopeptides and proteins in 


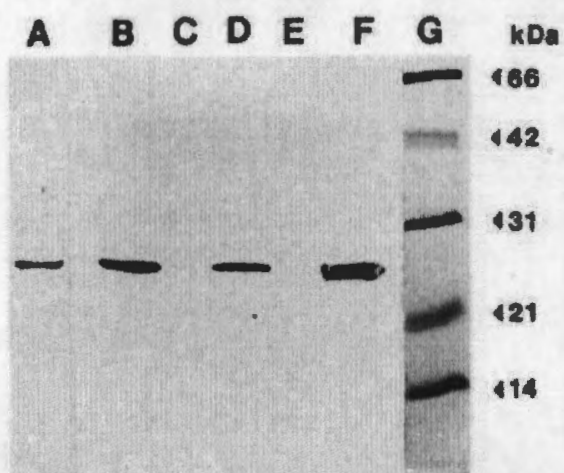

Flg. 1. Wostem blot analysis of cell oxtracts and Mip protein using antserum prepared anainst the Mip-positive E. coll K-12 clone HB101 (p8LLL3038). Lanes: A, cell extract of $L$ pnowmophlia Philadelphila $1 ; B$, cell extract of $E$. coll K-12 (pBLL3038); C. cell extract of $E$. coll K-12 (pLAFR2) (control); 0 , cell extract of $E$. coll K.12 (p8LL108); E, coll extract of $E$. collK-12 (pBR322) (control); $F$, purlied Mip protein of $E$. coli K-12 (pBLL106); G, molocular wolght markers (BioRad Laboratorles).

vitro (Lang et al., 1987; Fischer and Schmid, 1990; Tropschug et al., 1989). Recently, it has been suggested that the timing of the triple-helix formation of procollagen I in chick-embryo tendon fibroblasts is related to PPlase activity in vivo (Steinman ot al,, 1991). In addition, Immunophilins and their complexes with FK506 or cyclosporin A seem to play a key role in the signal-transduction pathways of T cells (Schreiber, 1991).

In order to test whether both PPlase activity and FK506 sensitvity are conserved within the Legionella Mip protein, we have cloned and sequenced the corresponding gene from strain L. pneumophila Philadelphia I and have purified the protein. It is shown that Mip has PPlase activity which approximates the same level as that found in the eukaryotic FKBPs. The PPlase activity of Mip is strongly inhibited by $100 \mathrm{nM}$ FK506 but is completely resistant to micromolar concentrations of cyclosporin $\mathrm{A}$.

\section{Results}

\section{Cloning and expression in Escherichia coli $K-12$ of the mip gene from L. pneumophila strain Philadelphia I}

A genomic library of $L$. pnoumophila Philadelphia I (Hacker et al., 1991; Ludwig ot al., 1991) was screened by immuno-colony blotting using anti-Legionella-specific antiserum. Seventy-six clones reacted strongly and the cell lysates were further analysed by SDS-polyacrylamide gel electrophoresis (PAGE) and Western blotting. Proteins of $24 \mathrm{kDa}$ were produced by 21 recombinant clones. DNA isolated from each of these clones was found to react in a DNA-DNA dot blot using a 30-mer oligonucleotide probe with a mip-specific sequence (Engleberg et al., 1989). A BamHI-Clal DNA fragment of $4.5 \mathrm{~kb}$ was subcioned from one of the cosmid clones, HB101(pBLL3039), into the vector pBR322. Western blots with a polyclonal monospecific anti-Mip-antiserum showed that the resulting clone, HB101(pBLL106), produced the Mip protein (Fig. 1).

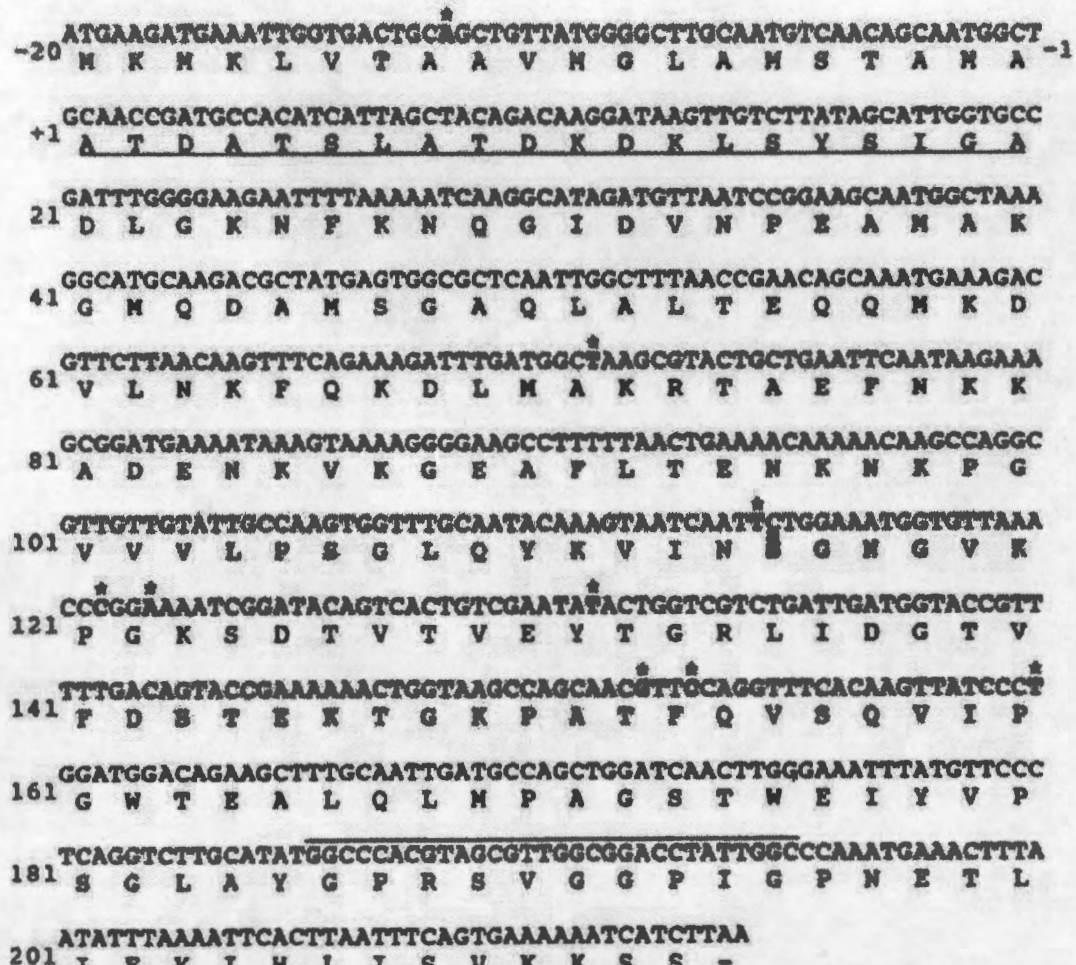




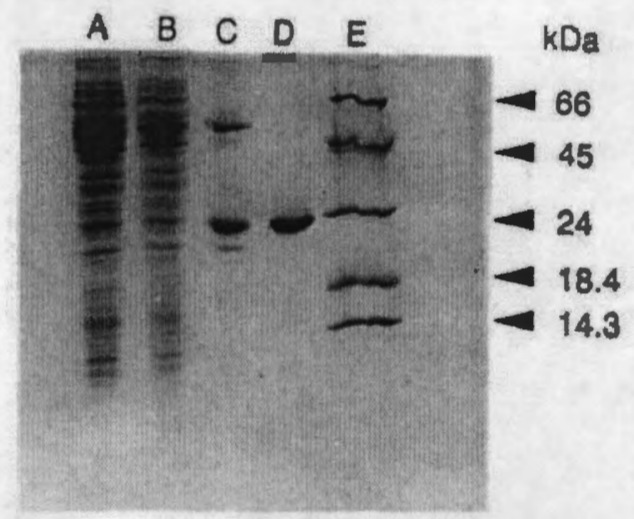

Fig. 3. Purtilication of recombinant Mip protein. The various fractions were subjected to SDS-PAGE and protein was stained with Coomassie brillant blue. Lanes: A, crude cell extrect of subcione HB101 (pBLLL106): $B$, Mip containing fractions after DEAE-sephacel passage; $C$, Afligel-blue chromatography; D, combined phenyl-sepharose fractions; F, molecular weight markers (Stgma).

DNA sequence of the mip determinant of strain $L$. pnoumophila Philadelphia I

The DNA sequence of the mip gene from strain Philadelphia I was determined (Fig. 2). This sequence revealed nine nucleotide substitutions relative to the mip sequence of strain Wadsworth (Engleberg et al., 1989). One of these substitutions resulted in the replacement of an alanine at amino acid position 115 with serine. The other eight nucleotide substitutions did not lead to alterations of the Mip amino acid sequence.

\section{Isolation of the recombinant Mip protein}

As shown in Fig. 3 and lane F of Fig. 1, the Mip protein of approximately $24 \mathrm{KDa}$ produced by clone HB101 (pBLL106) was isolated and obtained in a purified form using a four-step procedure. Table 1 summarizes the steps and yields as well as the enrichment factors thus obtained. No contaminating cyclophilin-like E. coli PPIases could be detected in the final Mip preparation.

Table 1. Puritication steps leading to homogeneous Mip-PPlase.

\begin{tabular}{llllll}
\hline & $\begin{array}{l}\text { Total } \\
\text { protein } \\
\text { (mg) }\end{array}$ & $\begin{array}{l}\text { Total Mip } \\
\text { activity } \\
\text { (arbitrary } \\
\text { units) }\end{array}$ & $\begin{array}{l}\text { Specific activity } \\
\text { (artitrary units } \\
\text { per mg protein) }\end{array}$ & $\begin{array}{l}\text { Recovery } \\
(\%)\end{array}$ \\
\hline Purification step & DEAE-Sephecel" & 275 & 4152 & 15 & 100 \\
TSK Affigel Blue & 4.7 & 1020 & 215 & 30 \\
Phenyl-Sepharose & 0.61 & 346 & 568 & 12 \\
\hline
\end{tabular}

- Mip activity measured loward Suo-Na-Pro-Phe-4-nitroanilide; differentiation of Mip enzymatic acitity from E. coll PPlase is only posstble atter the DEAE-Sephacel step

\section{N-terminal protein sequence of Mip}

In order to demonstrate that the isolated $24 \mathrm{kDa}$ polypeptide was indeed Mip, N-terminal sequencing of the mature protein was undertaken. As indicated in Fig. 2, the Initial amino acids of the mature protein are alanine, threonine, and aspartate. This clearly demonstrates a cleavage of the first 20 amino acids following transport. Each of the 20 $\mathrm{N}$-terminal amino acid residues of the mature Mip protein are identical to those predicted from the DNA sequence of mip indicated in Fig. 2.

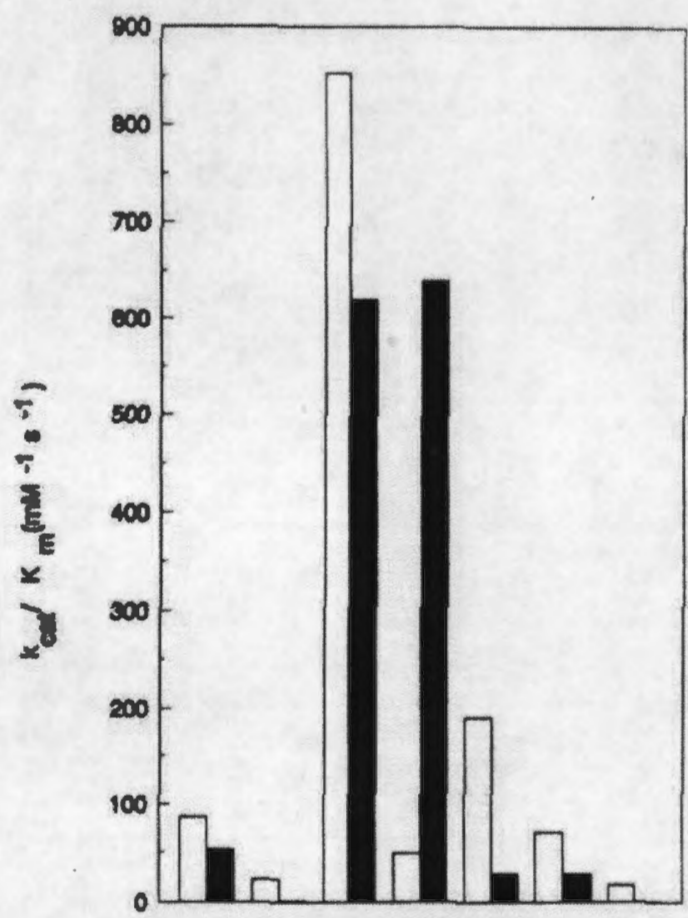

Xan - An chy Phe Les lys his Clu

Fig 4. Comparison of the speciticly constants $K_{\operatorname{cm}} / K_{m}$ of Mip PPlase (40-293 nM) activity (open columns) and humen FKBP (ahndowed columns, date from Harrison and Stein, 1990) toward Suc-Ale-Xag-ProPhe-4-nitroanilide (pH 7.8;0.035 $\mathrm{M}^{-9}$ HEPES buffer) at $10.0^{\circ} \mathrm{C}$.

\section{Determination of PPlase activity of Mip}

The Mip protein was tested for PPlase activity upon SucAla-Xaa-Pro-Phe-4-nitroanilide with the aid of isomerspecific proteolysis using chymotrypsin as the protease. The particular conditions of the assay result in $K_{\mathrm{con}} / K_{\mathrm{m}}$ for the cisitrans isomerization of the -Xaa-Pro bond.

We found enzymatic activity which slightly exceeds the highest value of $K_{b e r} / K_{m}$ observed for eukaryotic FKBPs (Fia. 4) using the most favoured substrate, Suc-AlaPho-Pro-Phe-4-nitroanilide. Mip additionally shows an elevated activity towards a substrate with a Lys in the $P_{\text {, }}$ position (using the nomenclatural system proposed by Schechter and Berger (1967) for the reactive peptide 


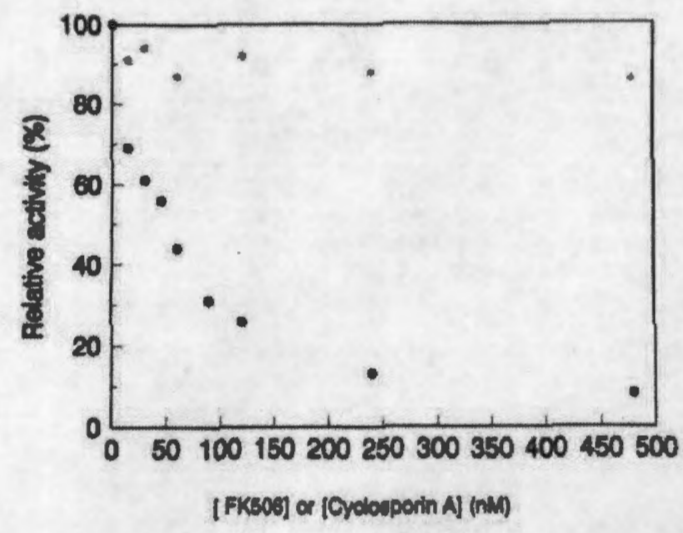

Fig. 5. PPlase activity as a tunction of the cyclosporin $A(*)$ and of the FK506 (0) concentration.

bond of oligopeptide substrates). The characteristic 5-10fold drop in activity for the entire set of substrate peptides that was found in prokaryotic and eukaryotic cyclophilinlike PPlases (G. Fischer, H. Bang, M. A. Marahiel, R. Schönbrunner and F. X. Schmid, submitted for publication) is not observed with FKBPs.

More interestingly, Mip lacks the pronounced Leu specificity for the $P_{1}$ position demonstrated for human FKBP (Harrison and Stein, 1990). A 600-fold decrease of $K_{\text {car }} / K_{m}$ was determined for human FKBP in Xaa =Gly cisitrans isomerization. This value, like that obtained using the human FKBP optimal substrate, was significantly reduced in Mip. This suggests that the hydrophobicity of the amino acid side chains cannot satisfactorily explain the influence of the $P_{1}$-amino acid on catalysis in Mip. The control strain HB101(pBR322) does not exhibit any PPIase activity with a specificity pattern similar to the Mip enzyme.

\section{Inhibition studies with FK506 and cyclosporin A}

As it was shown that all FKBPs possessing PPlase activity could be inhibited with nanomolar amounts of FK506 (Tropschug ot al., 1990; Siekierka ot al., 1990), we decided to examine the effect of increasing concentrations of FK506 as well as those of cyclosporin A, the inhibitor of cyciophilin-like PPlases, upon the enzymatic activity of Mip (Fig. 5). PPlase activity could be considerably influenced by FK506 although it was not significantly Inhibited by cyclosporin $A$ or by the non-immunosuppressive cyclosporin $\mathrm{H}$. The $I_{50}$ value $(50 \%$ inhibitory concentration) calculated from the data of Fig. 5 is about $45 \mathrm{nM}$, indicating that the $K_{1}$ value may be even smaller.

\section{Discussion}

The amino acid sequence of the Mip protein, a virulence factor of L. pneumophila (Clanciotto et al., 1989), the aetiological agent of Legionnaires' disease in humans, shows homology to amino acid sequences of human, Neurospora and yeast FK506-binding proteins (Standaert of al., 1990; Maki et al., 1990; Tropschug ot al., 1990; Wiederrecht et al., 1991; Jin et al. 1991; Lane et al., 1991; see Fig. 6). Cyclophilins and eukaryotic FKBPs represent a family of peptidyl-prolyl cis/trans isomerases (PPlases) termed immunophllins which can catalyse slow cis/trans interconversion of prolyl imidic peptide bonds in oligopeptides and proteins (Lang ot al., 1987; Fischer ot al., 1989; Fischer and Schmid, 1990; Tropschug et al., 1989; Price ot al., 1991; Schreiber, 1991).

When we tested the recombinant Mip protein cloned from L. pneumophila strain Philadelphia I we found PPIase activity comparable in magnitude to other cyclophilintype prokaryotic PPlases and to eukaryotic FKBPs. The comparison of the $P_{1}$ subsite specificity of the recombinant Mip with human FKBP (Fig. 4) results in a slightly different pattern of $K_{\text {cat }} / K_{m}$. The highest catalytic constant that could be obtained for the peptide with $X a a=P h e$ $\left(850000 \mathrm{M}^{-1} \mathrm{~s}^{-1}\right)$ exhibits an 18-fold lower activity when compared with the highest activity yet measured for a PPlase (pig kidney $17.8 \mathrm{kDa}$ cyclophilin acting on Suo-Ala-Ser-Pro-Pho-4-nitroanllide). The clear dependence of $k_{\text {cat }} / K_{m}$ on hydrophobicity of the $P_{1}$ amino acid side chain using human FKBP (Harrison and Stein, 1990) is not valid in Mip catalysis as even charged side chains can fulfil the requirements for favourable catalytic interactions.

The inhibitory effect of FK506 on Mip is similar of that observed for human FKBP although the interaction may be slightly weaker. However, the large PPlase concentrathon of $47 \mathrm{nM}$ used in our inhibition assay does not allow us to determine a $K_{1}$ range much smaller than this value. As in the case of $P_{1}$ subsite specifity, this may result from either the N-terminal extension of Mip or the variable amino acids located in the FKBP analogue C-terminal part (Fig. 6).

As indicated in Fig. 6, unidentified open reading frames (URFs) in the genome of the bacterial pathogens Neisseria meningitidis (Perry et al., 1987) and Pseudomonas aeruginosa (Kato ot al., 1989) resembling FKBPs are located in close proximity to virulence-associated loci, near two silent copies of truncated pilin genes in $N$. meningitidis and a region encoding regulatory proteins involved in the alginate biosynthesis of $P$. aeruginosa. Furthermore, Mip of $L$. pneumophila is closely related to a homologous protein of Legionella micdadei (Bangsborg et al., 1991) and to the L2 protein of Chlamydia trachomatis (Lundemose et al., 1991). Both are pathogenic organisms that exhibit virulence features similiar to those of L. pneumophila (Moulder, 1985; Horwitz, 1988). The possibility that putative gene products of the URFs and of 


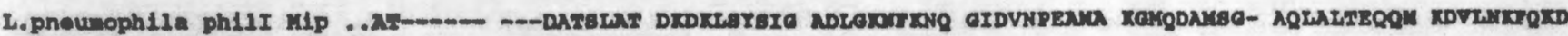

tuwan ( $O Y$ ) TKBP

Human (new) FKBP

Bovine bxap

S.cerovideiae FKBP

N. craese Frap

N..oningitidis ur

c. trachoust 1e raprotaln

L. Il codadol Hip

P. acruginose int

Coneensus equence

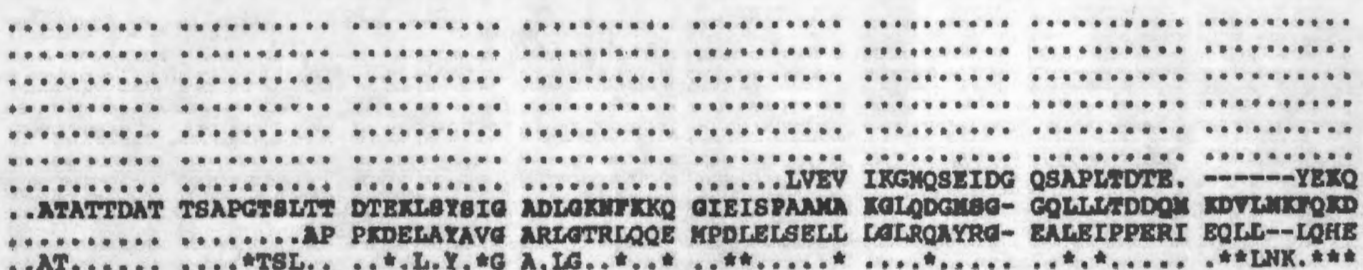

P.

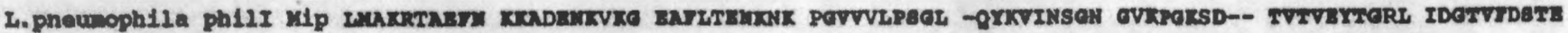

Human (oy) TXBP

Human (n) TKBP

Bovine rop

B. ourevilita Fap

H. craena RKBP

N. meningitidis uR

C. trachomat1s I3proted in

L. mL cdadel Mip

P. aeruginosa URF

Consensus sequence

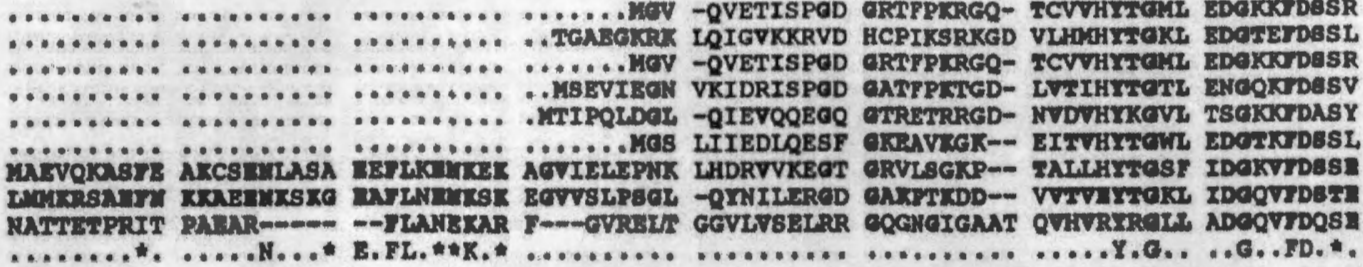

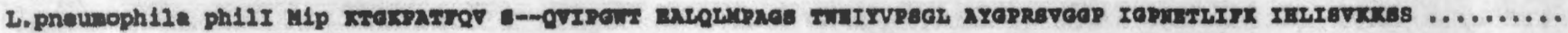

tiuman $(c y)$ Mxap

Human (ede) Trop

Bovine Has

B.cerevitula Txap

H. crasea FXBP

H. Ceningltide UR

C. trachoant1 teprotein

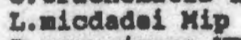

P.aeruginosa UR

Consencue secruena

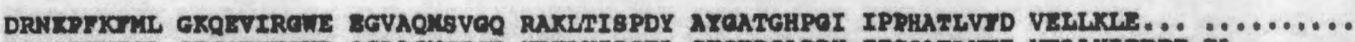

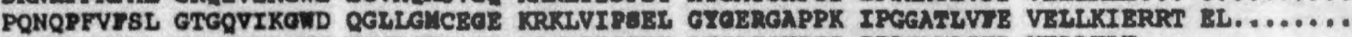

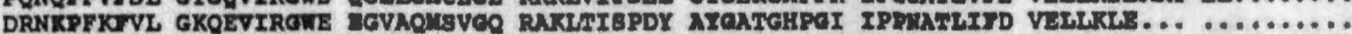

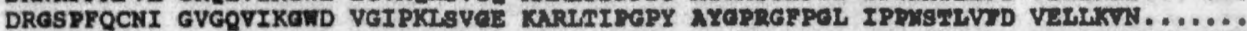

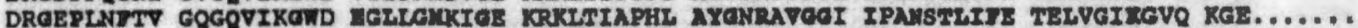
DRROP

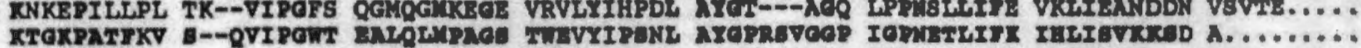

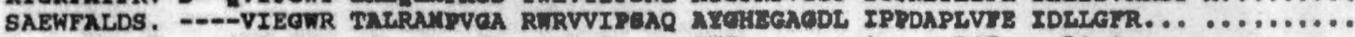

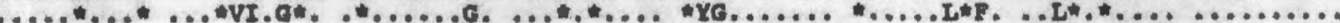

Fig. B. Comparison of the amino acid sequences of FKBPs exhibiting PPlase activity (Neurospora crassa, Saccharomycis cerevisiae, human Jurkat T cells [Cy FKBP], human cancer cell line (mem FKBP], and bovine calf thymus cells), and amino acid sequences of the mature Mip-fike protein of $L$. micdadej, the C-terminal part of the L2 protein of Chlamydia trachomatis, parts of unidentified open reading frames (URFs) of Neisseria meningittdis and $P_{\text {seudomonas }}$ aenginosa and the mature L. pneumophita (L.p.) Mip protein of strain Philadelphia t. Identical amino acid residues are indicated in bold type. Dashes represent gaps for optimal alignment. lsofunctional replacements are indicated by asterisks. Abbreviations: oy, cytoplasmic; mem, membrane-bound.

the L. micdadei mip as well as of the $L 2$ locus also influence the pathogenicity of the respective organisms cannot be excluded.

It has been shown recently that a genetically englneered mip mutant of $L$. pneumophila strain Wadsworth was defective in its ability to initiate macrophage infection (Clanciotto et al., 1989; 1990b). Cloning of the mip locus from another pathogenic Legionella isolate, Philadelphia I (Fig. 2), confirms the view that mip is highly conserved among all Legionella strains (Cianciotto ot al., 1990a). This suggests a common function for the protein in different isolates. The role of Mip enzymatic activity in Legionella virulence has yet to be elucidated. It is possible that the Mip protein modifies bacterial cell structures or surface proteins of the phagocytic cell, thereby enhancing their phagocytic capacity. A further possibility is that the Mip protein activity in the phagocytic cell could modily proteins to inhibit phagosome-lysosome fusion and acidification of the vacuole (Honwitz, 1983; Honwitz and Maxtield, 1984). Alternatively, a deregulation of signal-pathway proteins in phagocytes cannot be ruled out.

A large number of extracellular substances with enzymatic activities such as phospholipases, lecitinases, proteases or sugar transferases, some of which are membrane-associated, have been shown to contribute to the pathogenicity of bacteria (see Finlay and Falkow, 1989). The Legionella Mip protein, exhibiting PPlase activity reminiscent of that found in FKBPs, is an example of a bacterial virulence factor possessing characteristics normally observed in eukaryotes. A further example of a protein in pathogenic bacteria with enzymatic capacity normally ascribed to eukaryotes was recently detected in Yersinia. This genus comprises the species Yersinia pestis, the causative agent of plague. The YopH protein of Yersinia exhibits tyrosine phosphatase activity which is able to influence the phosphorylation pattern of the oukaryotic cell (Guan and Dixon, 1990; Bliska ot al,, 1991). Like Legionella, Yersinia is also able to replicate intracellularly. One may speculate that prokaryotic proteins with enzymatic functions related to eukaryotic cell signal factors represent a new general class of gene products which contribute to survival and dissemination of intracellular bacterial pathogens.

\section{Experimental procedures}

Media, enzymes and chemicals

Legionella strains were cultivated on buffered charcoal-yeast 
extract (BCYE) agar plates at $37^{\circ} \mathrm{C}$ in a $5 \% \mathrm{CO}_{2}$ atmosphere for $48 \mathrm{~h}$ prior to use. E. coll K-12 strains were grown in L-broth. Radiochemicals were purchased from NEN Research Products. Restriction enzymes, T4 polynucleotide kinase and T4 ligase were obtained from Pharmacia, Boehringer, Biolabs, and Gibco BRL. All other chemicals were obtained from Merck, Difco, BRL, Oxoid, Roth, and Serva. Antibiotics were from Serva or Sigma.

\section{Bacterial strains and plasmids}

The genomic library was constructed from $L$ pneumophila strain Philadelphia I (McDade ot al., 1877). For cloning experiments, the $E$. coli K-12 strain HB101 was used. Plasmid pLAFR2 is a cosmid vector described previously (Knapp and Mekalanos, 1988). For subcloning, vector pBA322 (Bolivar ot al., 1977) was used. Antibiotics were added at concentrations of $50 \mu \mathrm{g} \mathrm{m}^{-1}$ (ampicillin) and $10 \mu \mathrm{g} \mathrm{m}^{-1}$ (tetracycline).

\section{Cosmid cloning procedure}

Legionolla-specific chromosomal DNA was isolated as described (Ludwig et al., 1991; Wintemeyer ot al., 1991). Large (20 kb) chromosomal Sau3A fragments were ligated into the BamHI site of cosmid pLAFR2 and transduced into HB101 with the help of the cosmid packaging system (Hohn and Collins, 1980).

\section{Recombinant DNA techniques}

Plasmid DNA was isolated as described (Bimboim and Doly. 1979). For restriction enzyme analysis, DNA was treated with appropriate enzymes and the resulting fragments were separated by gel electrophoresis on $0.8-1.0 \%$ agarose gels (Sambrook of al., 1989). DNA fragments were isolated from the agarose gel with the help of the GeneClean kit from Bio101 as described by a protocol of the manufacturer. For cloning, DNA fragments were ligated into suitable vector molecules after heat-inactivation of the restriction endonucleases at $65^{\circ} \mathrm{C}$ for $10 \mathrm{~min}$ (Sambrook ot al., 1989). E. coll K-12 strains were transformed by the $\mathrm{CaCl}_{2}$ method (Lederberg and Cohen, 1974).

\section{Oligonucleotide synthesis}

Oligonucleo' tes used for DNA sequencing and DNA-DNA dol blotting wer synthesized with an Applied Biosystems $380 \mathrm{~A}$ DNA symthesizer using the phosphoramidite method of Beaucage and Caruthers (1981). Oligonucleotides were purlfied with oligonucleotide purification cartridges from Applied Biosystems.

\section{DNA sequencing}

The sequence of the mip-specific DNA region was determined with the help of a sequencing kit from Boehringer, as described by a protocol of the manulacturer.

\section{Computer analysis}

The programs used for compiling the nucleotide sequence data were from J. Devereux (University of Wisconsin Genetics Computing Group).

\section{DNA-DNA dot blotting}

As a mip-specific probe the oligonucleotide 5'-GGCCCACGTAGCGTTGGCGGACCTATTGGC-3* (see Fig. 2) was used. The probe was labelled by T4 polynucleotide kinase using $\left[r^{33}\right.$-P]-ATP. The DNA dot blotting procedure and hybridization were carried out according to Sambrook ot al. (1989).

\section{Preparation of antisera}

The antigen used for production of the $L$. pneumophila-specific antiserum was prepared from heat-killed $L$. pneumophlla strains grown on agar plates as described (Hacker ot al., 1991). Antiserum was prepared by intravenous injection of the antigen into New Zealand rabbits. The final immunofluorescence titre (IFT) of the antiserum was 1:1024. Antiserum specific for the cloned Mip protein of L. pneumophila was prepared from E. coli K-12 clone HB101(pBLL3039). The final IFT was 1:512. To remove the $E$. coll $K-12$-specific antibodies the antiserum was absorbed with a suspension of HB101 (pLAFR2).

\section{Immuno-colony blotting}

Immuno-colony blots were made as described by Van Die et al. (1985).

\section{Western blotting}

For Western blotting, $10 \mathrm{ml}$ of overnight culture of the recombinant E. coll K-12 clones or an equal amount of L. pneumophila cells harvested from agar plates was pelleled by centrifugation at $4^{\circ} \mathrm{C}$ for $10 \mathrm{~min}$ and washed with $10 \mathrm{mM}$ ice-cold HEPES buffer (pH 7.4). Cell pellets were suspended in $1 \mathrm{ml} 10 \mathrm{mM}$ HEPES buffer ( $\mathrm{pH} 7.4)$. The suspensions were passed through a French press $(3 \times 6210 \mathrm{kPa})$ and residual cells were removed by centrffugation. Proteins were analysed by SDS-PAGE as described by Laemmli (1979). The Western blots were performed according to the method of Kyhse-Andersen (1984).

\section{Protein sequencing}

The protein was subjected to $12.5 \%$ SDS-PAGE and blotted on to PVDF membranes (Immabilon transfer; Millipore) as described by Choli ot al. (1989). The Mip protein was sequenced in an Applied Biosystem 470 A gas-phase sequencer.

\section{Isolation and purrification of the Mip protein}

For isolation of the Mip protein, cells from $10 \mathrm{I}$ of ovemight cultures of the recombinant $E$. coll $\mathrm{K}-12$ clone HB101 (pBLL106) were pelleted by centrifugation at $4^{\circ} \mathrm{C}$ for $10 \mathrm{~min}$ at 10000 r.p.m. and washed with $10 \mathrm{mM}$ ice-cold HEPES buffer (pH 7.4). Bacterial cells were suspended in $50 \mathrm{ml}$ of $10 \mathrm{mM}$ HEPES buffer (pH 7.4), passed through a French press $(3 \times 6210 \mathrm{kPa})$ and cell debris were removed by centrifugation for $20 \mathrm{~min}$ at 20000 r.p.m. (in a Kontron T 324 centriluge; A 8.24 rotor). Polymin P (BASF) was added to the supernatant to 
give a final concentration of $0.4 \%$. After being stirred for 30 min, the solution was centrifuged as described above. The supernatent was applied to a DEAE-Sephacel column $(2.5 \mathrm{~cm}$ 1.d. $\times 35 \mathrm{~cm}$ ) equilibrated in $35 \mathrm{mM}$ HEPES (pH 7.8). In contrast to $E$. coll PPlase, the Mip protein does not bind to this material. Enzymatically active fractions were applied to a $1.5 \mathrm{x}$ $15 \mathrm{~cm}$ Affigel-blue column (Merck) equilibrated with $35 \mathrm{mM}$ HEPES ( $\mathrm{pH} 7.8$ ). Under such conditions the Mip protein adsorbs to the affinity column. Approximately $80 \%$ of the protein could be recovered when eluted with $200 \mathrm{ml}$ of $2 \mathrm{mM}$ Tricin (pH 8.5).

Mip activity was eluted by applying a linear gradient $(300 \mathrm{ml}$ total) of $0-400 \mathrm{mM} \mathrm{KCl}$ in $2 \mathrm{mM}$ Tricine (pH 8.5). Active fractions (at approx. $240 \mathrm{mM} \mathrm{KCl}$ ) were pooled and $\mathrm{KCl}$ was added to a total concentration of $0.5 \mathrm{M}$ to the pool prior to pumping the sample on to a $0.5 \times 5 \mathrm{~cm}$ phenyl-sepharose column in $2 \mathrm{mM}$ Tricine, $0.5 \mathrm{M} \mathrm{KCl}$, (pH 8.5). The following elution was then carried out using a $50-\mathrm{ml}$ step gradient, starting with $2 \mathrm{mM}$ Tricine (pH 8.5), followed by addition of $0.1 \%$ Triton $X-100$ and ending with $3 \%$ Triton X-100. The homogeneity of Mip was verified by silver-staining after SDS-PAGE. The recovery of Mip was about $10 \%$ with respect to the Mip enzymatic activity found after separation from the $E$. coll PPlases. For sequencing, salts were diluted out from the protein with water using Centricon C 10 fittration (Amicon).

\section{PPlase assay}

Enzymatic activity was measured in $0.035 \mathrm{M}$ HEPES buffer (pH 7.8) at $10^{\circ} \mathrm{C}$ using the protease-coupled assay described previously (Fischer at al., 1989). Briefly, with respect to the prolyl bond the substrates Succiny-Ala-Xaa-Pro-Phe-4nitroanilide (Bachem) exist at pH 7.8 in an equilibrium of about 5-20\% cls and $80-95 \%$ trans conformer. Alpha-chymotrypsin cannot readily split off the 4-nitroaniline residue in the cis conformer. In the presence of $0.5-1.0 \mathrm{mg} \mathrm{m}^{-1} \alpha$-chymatrypsin to perform rapid cleavage of the trans substrate it remains uncleaved in the solution. Because the cis form is subject to a slow isomerization reaction leading to the cleavable trans substrate, consumption of the total amount of the chromogenic peptide is achieved after several minutes. In the presence of PPlase activity the slow kinetic phase of appearance of 4nitroaniline following the trans cleavage is a composite of the uncatalysed $\left(k_{1}\right)$ and the PPlase-catalysed $\left(k_{\text {wna }}\right)$ cis to trans interconversion. Thus, the first-order kinetics obtained can be described by the rate equation $v=k_{\text {obo }}[c i s] ; k_{\text {ote }}=k_{1}+k_{\min }$.

For all substrates used in the assay the range of total substrate concentrations was limited to $0.06-0.02 \mathrm{mM}$. Under the reaction conditions described above, the following rate constants of the uncatalysed cis to trans isomerization $\left(k_{1}\right)$ have been determined: $\mathrm{Xaa}=\mathrm{Ala}\left(0.0076 \mathrm{~s}^{-1}\right)$; Phe $\left(0.0043 \mathrm{~s}^{-1}\right)$; Leu $\left(0.0073 \mathrm{e}^{-7}\right)$; Lys $\left(0.0055 \mathrm{~s}^{-7}\right)$; Gly $\left(0.0060 \mathrm{~s}^{-1}\right)$; His $\left(0.0059 s^{-5}\right)$; Glu $\left(0.0034 s^{-1}\right)$. Utilizing reaction conditions at high Mip-PPlase concentrations $\left(k_{1}<<k_{\text {ena }}\right)$ and rapld monitoring of the slow phase of the reaction (first data points after $5 \mathrm{~s}$ ) it could be shown that the time-course of the 4-nitroaniline appearance is strictly first-order in rate throughout the reaction. The result shows that the relationship $k_{0 b} /[P P l a s e]=k_{\text {can }} / K_{m}$ holds true for all of the substrates. This was more directly indicated for bovine FK506-sensitive PPlase since the Michaelis constant, $K_{m}$ ( $0.52 \mathrm{mM}$ cis isomer) of Suc-Ala-Leu-Pro-Pho4-nitroanilide could be determined by measuring the V/S dependence at high substrate concentrations (Koiron ot al. 1991).

The PPlase assay was performed by adding a $1 \mu$ l aliquot of the peptide dissolved in dimethylsulphoxide (DMSO) to $1.1 \mathrm{ml}$ of the solution of $\alpha$-chymotrypsin (Merck) in the buffer containing Mip-PPlase, too. The concentration of Mip was determined by the Bradford procedure (1976). Stock solutions of the inhibitors were made in EtOH/water $(50 \% / 50 \%$, VW). For the kinetic runs a Hewlett Packard 8452 diode array UVNIS spectrophotometer was used for monitoring the time course of the difference in absorbance at $390 \mathrm{~nm}$ and $520 \mathrm{~nm}$. First-order rate constants ( $k_{\text {obe }}$ ) were calculated on the basis of $100-500$ data points covering at least two half-lives of the reaction.

\section{Acknowledgements}

This work was supported, in part, by grants from the BMFT (01 $\mathrm{Ki} 8829$ and $30 \mathrm{~K} \mathrm{008405)}$ and the Fonds der Chemischen Industrie. We thank Laurence R. Phillips (Würzburg) for critical reading of the manuscript.

\section{References}

Bangsborg, J.M., Clanciotto, N.P., and Hindersson, P. (1991) Nucleotide sequence analysis of the Legionella micdadei mip gene, encoding a 30-Kilodalton analog of the Legionella pneumophila Mip protein. Infect Immun 59: 3836-3840.

Beaucage, S.L., and Caruthers, M.H. (1981) Deoxynucleoside phosphoramidites: a new class of key intermediate for deoxypolynucleotide synthesis. Tetrahedron Letts 22: 1859-1862.

Birnboim, H.C., and Doly, J. (1979) A rapid alkaline extraction procedure for screening recombinant plasmid DNA. NuCl Acids Res 7: 1513-1522.

Black, W.J., Quinn, F.D., and Tompkins, L.S. (1990) Legionella pneumophila zinc metalloprotease is structurally and functionally homologous to Pseudomonas aeruginosa elastase. $J$ Bacleriol 172: 2608-2619.

Bliska, J.B., Guan, K.L., Dixon, J.E., and Falkow, S. (1991) Tyrosine phosphate hydrolysis of host proteins by an essential Yersinia virulence determinant. Proc Natl Acad Sci USA 88: 1187-1191.

Bolivar, F, Rodriguez, R.L., Greene, P.J., Betlach, M.C., Heyneker, H., and Boyer, H.W. (1977) Construction and characterization of new cloning vehicle. II. A multipurpose cloning system. Gene 2: 95-113.

Bradiord, M.M. (1976) A rapid and sensitive method for the quantitation of microgram quantities of protein utilizing the principle of protein-dye binding. Anal Biochem 72: 248-54.

Choll, T., Kapp, U., and Wittman-Liebold, J. (1989) Blotting of proteins onto immobilon membrane. In-site characterization and comparison with high periormance liquid chromatography. J Chromatog 476: 59-71.

Clanciotto, N.P., Eisenstein, B.I., Mody C.H., Toews G.B., and Engleberg, N.C. (1989) A Legionella pneumophila gene encoding a species-specific surface protein polentiates initiation of intracellular infection. Infect Immun 57: 1255-1262.

Cianciotto, N.P., Bangsborg. J.M., Eisenstein, B.I., and Engleberg, N.C. (1990a) Identilication of mip-like genes in the genus Legionella. Infect Immun 58: 2912-2918. 
Clanciotto, N.P., Eleenstein, B.I., Mody, C.H., and Engleberg. N.C. (1990b) A mutation in the mip gene results in an attenuation of Legionella pneumophilla virulence. $J$ Inf Dis 162: 121-126.

Engleberg. N.C., and Eisenstein, B.I. (1991) Progress in the pathogenesis of Legionella pneumophila. Microb Pathogen 10: $11-13$.

Engleberg, N.C., Carter, C., Weber, D.R., Clanciotto, N.P., and Eisenstein, B.I. (1989) DNA sequence of mip, a Legionella pneumophila gene associated with macrophage infectivity. Infect Immun 57: 1263-1270.

Finlay, B.B., and Falkow, S. (1989) Common themes in microbial pathogenicity. Microbiol Rev 53: 210-230.

Fischer, G., and Schmid, F.X. (1990) The mechanism of protein folding. Implications of in vitro refolding models for de novo protein folding and translocation in the cell. Biochemistry 29: 2205-2212.

Fischer, G., Wittmann-Liebold, B., Lang, K., Kiethaber, T., and Schmid, F.X. (1989) Cyclophilin and peptidyl-prolyl cis-trans isomerase are probably identical proteins. Nature 337: $476-478$.

Guan, K., and Dixon, J.K. (1990) Protein tyrosine phosphatase activity of essential virulence determinant in Yersinia. Science 249: 553-556.

Hacker, J., Ott, M., Ludwig, B., and Rdest, U. (1991) Intracellular survival and expression of virulence determinants of Legionella pneumophila. Infection 19: 198-201.

Harrison, R.K., and Stein, R.L. (1990) Substrate specificities of the peptidyl prolyl cis-trans isomerase activities of cyclophilin and FK506 binding protein: evidence for the existence of a family of distinct enzymes. Blochemistry 29: 3813 3816.

Hotiman, P.S., Houston, L., and Butler, C.A. (1990) Legionella pneumophila htp $\mathrm{AB}$ heat shock operon: nucleotide sequence and expression of the 60-kilodalton antigen in $L$. pneumophilainfected Hela cells. Infect Immun 58: 33803387.

Hohn, B., and Collins, J. (1980) Small cosmid for efficient cloning of large DNA iragments. Gene 11: 291-298.

Honwitz, M.A. (1983) The Legionnaires' disease bacterium (Legionella pneumophila) inhibits phagosome-lysosome fusion in human monocytes. J Exp Med 158: 2108-2126.

Horwitz, M.A. (1984) Phagocytosis of the Legionnaires' disease bacterium (Legionella pnoumophila) occurs by a novel mechanism: enguliment within a pseudopod coll. Cell 36: 27-33.

Honwitz, M.A. (1988) Phagocytosis and intracellular biology of Legionella pneumophila. In Bacteria, Complement and the Phagocytic Cell. Vol. 24. NATO ASI Series H, Berlin: Springer Verlag, pp. 231-237.

Honwitz, M.A., and Maxtield, F.A. (1984) Legionella pneumophila inhibits acidification of its phagosome in human monocytes. J Cell Biol 99: 1936-1943.

Jin, Y.J., Albers, M.W., Lane, W.S., Bierer, B.E., Schreiber, S.L, and Burakoft, S.J. (1991) Molecular cloning of a membrane-associated human FK506-and rapamycin-binding protein, FKBP-13. Proc Nati Acad Sci USA 88: 6677-6681.

Kato, J., Chu, L. Kitano, K., Devoult, J.D., Kimbara, K. Chakrabarty, A.M., and Misra, T.K. (1989) Nucleotide sequence of a regulatory reglon controlling alginate synthesis in Pseudomonas aeruginosa: characterization of the algR2 gene. Gene 84: 31-38.

Knapp, $\mathrm{S}_{\text {, }}$ and Mekalanos, J. (1988) Two trans-acting regulatory genes (virand mod) control antigenic modulation in Bordetella pertussis. J Bacteriol 170: 5059-5066.
Kofron, J.L., Kuzmic, P., Kishore, V., Colon-Bonilla, E., and Rich, D.H. (1991) Determination of kinetic constants for peptidyl prolyl cis-trans isomerases by an improved spectrophotometric assay. Biochemistry 30: 6127-34.

Kyhse-Andersen, J. (1984) Electroblotting of multiple gels: a simple apparatus without buffer tank for rapid transfer of proteins form polyacrylamide to nitrocellulose. J Biochem Biophys Meth 10: 203-209.

Laemmli, U.K. (1979) Cleavage of structural proteins during the assembly of the head of the bacteriophage T4. Nature 227: 680-685.

Lane, W.S., Galat, A., Harding, M.W., and Schreiber, S.L. (1991) Complete amino acid sequence of the FK506 and rapamycin binding protein, FKBP. isolated from call thymus. JProt Chem 10: 151-160.

Lang, K., Schmid, F.X., and Fischer, G. (1987) Catalysis of protein folding by prolyl isomerase. Nature 329: 268-270.

Loderberg, E.M., and Cohen, S.N. (1974) Transiormation of Salmonella typhimurium by plasmid deoxyribonucleic acid. $J$ Bacteriol 119: 1072-1074.

Ludwig, B., Schmid, A., Marre, R., and Hacker, J. (1991) Cloning. genetic analysis and nucleotide sequence of a determinant coding for a $19 \mathrm{kDa}$ peptidoglycan-associated protein (Ppl) of Legionella pneumophila. Infoct Immun 59: 2515-2521.

Lundemose, A.G., Birkelund, S., Fey, S.J., Larsen, P.M., and Christiansen, G. (1991) Chlamydia trachomatis contains a protein similar to the Leglonella pneumophila mip gene product. Mol Microbioi 5: 109-115.

McDade, J.E., Shepard, C.C., Fraser, D.W., Tsal, T.R., Redus, M.A., Dowdle, W.R., and the Laboratory Investigation Team (1977) Legionnaires' disease. Isolation of a bacterium and demonstration of its role in other respiratory disease. Now Engl J Med 297: 1197-1293.

Maki, N., Sekiguchi, F., Nishimaki, J., Miwa, K., Hayano, T., Takahashi, N., and Suzuki, M. (1990) Complementary DNA encoding the human T-cell FK 506-binding protein, a peptidyl-prolyl cis-irans isomerase distinct from cyclophilin. Proc Natl Acad Sci USA 87: 5440-5443.

Moulder, J.W. (1985) Comparative biology of intracellular parasitism. Microbiol Rev 49: 298-337.

Perry, A.C., Nicolson, I.J., and Saunders, J.R. (1987) Neisseria meningitidis $C 114$ contains silent, truncated pilin genes that are homologous to Neisseria gonormoeae pil sequences. $J$ Bacteriol 170: 1691-1697.

Price, E.F., Zydowsky, L.D., Jin, M., Baker, C. H., McKeon, F.D., and Walsh, C.T. (1891) Human cyclophilin B: a second cyclophilin gene encodes a peptidyl-prolyl isomerase with a signal sequence. Proc Nafl Aced Sci USA 88: 1903-1907.

Sambrook, J., Fritsch, E.F., and Maniatis, T. (1989) Molecular Cloning. A Laboratory Manual. 2nd edn. Cold Spring Harbor. New York: Cold Spring Harbor Laboratory Press.

Schechter, J., and Berger, A. (1967) On the size of the active site in proteases I. Papaine. Blophys Biochem Res Commun 27: 157-162.

Schreiber, S.L. (1991) Chemistry and biology of the immunophilins and their immunosuppressive ligands. Science 251: 283-287.

Siekierka, J.J., Wiederrecht, G., Greulich, H., Boulton, D., Hung, S.H.Y., Cryan, L., Hodges, P.d., and Sigal, N.H. (1990) The cytosolic-binding protein for the immunosuppressant FK506 is both a ublquitous and highly conserved peptidyl-prolyl cis-trans isomerase. J Biol Chem 265: 21011-21015.

Standaert, R.F., Galat, A., Verdine, G.L., and Schreiber, S.L. 
(1990) Molecular cloning and overexpression of the human FK506-binding protein FKBP. Nature 346: 671-674.

Steinmann, B., Bruckner, P., and Superti-Furga, A. (1991) Cyclosporin A shows collagen triple-helix formation in vivo: indirect evidence for a physiological role of peptidyl-prolyl cis/trans isomerases. J Biol Chem 266: 1299-1303.

Tropschug, M., Bartheimess, I.B., and Neupert, W. (1989) Sensithity to cyclosporin A is mediated by cyclophilin in Nourospora crassa and Saccharomyces cerevisiae. Nature 342: 953-955.

Tropschug, M., Wachter, E., Mayer, S., Schönbrunner, E.R, and Schmid, F.X. (1990) Isolation and sequence of an FK506-binding protein from $N$. crassa which catalyses protein folding. Nature 346: 674-677.

Van Die, I., van Geffen B., Hoekstra, W., and Bergmans, H.
(1985) Type 1 C fimbriae of an uropathogenic Escherichia coll strain: cloning and characterization of the genes involved in the expression of the $1 \mathrm{C}$ antigen and nucleotide sequence of the subunit gene. Gene 34: 187-196.

Wiederrecht, G., Brizuela, L, Elliston, K., Sigal, N.H., and Siekierka, J.J. (1991) FKB1 encodes a nonessential FK506blnding protein in Saccharomyces cerevisiae and contains regions suggesting homology to the cyclophilins. Proc Nat Acad Sci USA 88: 1029-1033.

Winn, W.C. (1988) Legionnaires' disease: historical perspective. Clin Microbiol Hev 1: 60-81.

Wintermeyer, E., Rdest, U., Ludwig, B. Debes, A $_{i,}$ and Hacker, J. (1991) Characterization of legiolysin (II), responsible for haemolytic activity, colour production and fluorescence of Legionella pneumophila. Mol Microbio/5: 1135-1143. 